\title{
COVID-19 and comorbidities: Predictors, clinical course, relationship with disease severity, and outcome
}

\author{
Emine Afsin', Mehmet Coşgun ${ }^{2}$ \\ ${ }^{I}$ Department of Chest Diseases, Bolu Abant Izzet Baysal University, School of Medicine, Bolu, Turkey \\ ${ }^{I}$ Department of Cardiology, Bolu Abant Izzet Baysal University, School of Medicine, Bolu, Turkey
}

\section{ABSTRACT}

\begin{abstract}
Aim: COVID-19 disease has a broad spectrum ranging from asymptomatic course to death. While data show that the prognosis of the disease will be poor in the presence of comorbidity, we witness the death of patients with no comorbidities in our clinical practice. This study aimed to investigate the effect of comorbidity on the clinical course and mortality of COVID-19 pneumonia.
\end{abstract}

Methods: 155 Rt-PCR (+) adult patients hospitalized at İzzet Baysal State Hospital (Bolu, Turkey) diagnosed with severe and critical pneumonia between August 2020 and February 2021 were included in this singlecenter, retrospective study. The patients were divided into two groups with and without comorbidity, compared the severity of inflammation parameters, radiological involvement, and oxygen requirement, and evaluated their effects on mortality and hospitalization duration.

Results: There was no significant difference in the severity of the computed tomography (CT) involvement, the oxygen requirement, inflammation markers, and duration of hospitalization in patients with comorbidities compared to those without. When we evaluated the patients with comorbidities in general and their subgroups, the relationship with mortality was not significant. The severity of CT involvement, high oxygen requirement, and inflammation markers such as lymphocyte, lymphocyte ratio, LDH, CRP, troponin, ferritin levels were found to be associated with mortality.

Conclusions: In this study, we found that the presence of comorbidity did not affect mortality and duration of stay and that the severity of radiological involvement, the severity of hypoxemia, and the increase in inflammation markers were the determinants of mortality.

Key words: COVID-19, coronavirus infections, pneumonia, comorbidity, outcome, mortality.

$\triangle D r$. Emine Afsin

Department of Chest Diseases, Bolu Abant Izzet Baysal University, School of Medicine, Bolu, Turkey

E-mail: emineafsin@yahoo.com

Received: 2021-07-02 / Revisions: 2021-07-24

Accepted: 2021-07-30 / Published online: 2021-10-01

\section{Introduction}

The COVID-19 pandemic has been in existence since the end of 2019, and the loss of life continues. The presence of comorbidity may affect the clinical course of COVID-19.
Diseases such as type 2 diabetes mellitus (DM), hypertension (HT), atherosclerotic cardiovascular (CVS) diseases, and chronic obstructive pulmonary disease (COPD) increase the risk [1]. In some studies, HT (30\%) [2] and in others, diabetes mellitus [3] is the most common comorbidity, causing high mortality rates. Although the prevalence of COPD is low, it exacerbates the clinical course and significantly increases mortality in its presence [4]. It was reported that cancer is not 
common comorbidity in COVID-19 patients, and less mechanical ventilation requirement and mortality rates were reported in cancer cases [5]. In light of this information, we aimed to retrospectively investigate the frequency of comorbidities and the relationship of existing comorbidities with mortality and clinical course in Rt-PCR positive severe and critical hospitalized COVID-19 pneumonia patients.

\section{Materials and methods}

The single-center, retrospective study was performed with patients hospitalized in the inpatient clinic and intensive care unit of İzzet Baysal State Hospital. This study was approved by Abant İzzet Baysal University Ethics Committee (Date: 2021-10-06 / No:189).

One hundred fifty-five patients with severe and critical pneumonia, according to WHO interim guidance [6], among Rt- PCR (+) COVID-19 patients were included. Patients under the age of 18, pregnant and postpartum patients, patients with missing comorbidity information, $\mathrm{CT}$, and laboratory parameters were excluded. Demographic, radiological (pulmonary involvement less than or above $50 \%$ in CT imaging), laboratory data, and treatment outcome of the patients were recorded retrospectively. The severity of oxygen requirement was grouped as mild (up to $5 \mathrm{~L} / \mathrm{min}$ with the nasal cannula) and heavy (including mask, mask with reservoir, high flow nasal oxygen (HFNO), intubated follow up). Their comorbidities were grouped as HT, DM, $\mathrm{DM}+\mathrm{HT}$, chronic pulmonary disease (CPD), cardiovascular system diseases (CVSD), malignancy, connective tissue diseases (CDD), and other (such as goiter, chronic kidney failure, which we could not group).

The analysis of the data obtained as a result of the research was performed in the SPSS 20 statistical package program, and descriptive statistical methods (frequency, arithmetic mean, standard deviation, cross tables) were used. Compliance with normal distribution was evaluated with the Kolmogorov-Smirnov test. The arithmetic mean of the normally distributed groups was evaluated, and the Independent Sample t-test compared two independent groups. The medians of the non-normally distributed groups were determined, and the Mann-Whitney $U$ test compared two independent groups, and the Chi-Square test examined the relationship between categorical variables. A p-value of $<0.05$ was considered statistically significant.

\section{Results}

The mean age of the patients was 68 years (3195), and the relationship between mortality and age was significant (61 years (31-95) in survivors, 70 years (48-94) in non-survivors, $p$ : 0.002). The group with comorbid diseases was older (69 (35-95) vs. 57.5 (31-94) p: 0.001).

The overall comorbidity rate in the patients was $73 \%$, with HT $49.7 \%$, DM 29\%, DM+HT $21.3 \%$, CPD $14.8 \%$, CVSD 9\%, malignancy $5.2 \%$, CDD $1.9 \%$, and $18.7 \%$ for other diseases (few diseases we did not group, such as goiter, chronic kidney disease). The rate of noncomorbid patients was found to be $27.1 \%$. When the patients with comorbidities were evaluated in general and according to their subgroups, the relationship with mortality was not statistically significant ( $p>0.005$, Table 1$)$. There was no significant difference in the severity of the CT involvement, the severity of the oxygen requirement, inflammation markers, and duration of stay in patients with comorbidities compared to those without ( $p>0.05$, Table 2). In terms of duration of hospital stay, a significant difference was found only in the DM and DM+HT subgroups, with a shorter duration of stay. 
Table 1. The relationship between the presence of comorbidity and mortality.

\begin{tabular}{|c|c|c|c|c|}
\hline Parameters & $\begin{array}{c}\text { Survivor }(\mathrm{N}=113) \\
(\mathrm{N} / \%)\end{array}$ & $\begin{array}{c}\text { Non-survivor }(\mathrm{N}=42) \\
(\mathrm{N} / \%)\end{array}$ & $\begin{array}{c}\text { Total }(\mathrm{N}=155) \\
(\mathrm{N} / \%)\end{array}$ & p-value \\
\hline $\begin{array}{l}\text { DM } \\
\text { Non- DM }\end{array}$ & $\begin{array}{l}37 / 82.2 \\
76 / 69.1\end{array}$ & $\begin{array}{c}8 / 17.8 \\
34 / 30.9\end{array}$ & $\begin{array}{l}45 / 29 \\
110 / 71\end{array}$ & 0.095 \\
\hline $\begin{array}{l}\text { HT } \\
\text { Non- HT }\end{array}$ & $\begin{array}{l}60 / 77.9 \\
53 / 67.9\end{array}$ & $\begin{array}{l}17 / 22.1 \\
25 / 32.1\end{array}$ & $\begin{array}{l}77 / 49.7 \\
78 / 50.3\end{array}$ & 0.162 \\
\hline $\begin{array}{l}\text { DM+HT } \\
\text { Non- (DM+HT ) }\end{array}$ & $\begin{array}{l}27 / 81.8 \\
86 / 70.5\end{array}$ & $\begin{array}{c}6 / 18.2 \\
36 / 29.5\end{array}$ & $\begin{array}{c}33 / 21.3 \\
122 / 78.7\end{array}$ & 0.194 \\
\hline $\begin{array}{l}\text { CVSD } \\
\text { Non- CVSD }\end{array}$ & $\begin{array}{l}10 / 71.4 \\
103 / 73\end{array}$ & $\begin{array}{l}4 / 28.6 \\
38 / 27\end{array}$ & $\begin{array}{c}14 / 9 \\
141 / 91\end{array}$ & 0.896 \\
\hline $\begin{array}{l}\text { CPD } \\
\text { Non-CPD }\end{array}$ & $\begin{array}{l}17 / 73.9 \\
96 / 72.7 \\
\end{array}$ & $\begin{array}{c}6 / 26.1 \\
36 / 27.3 \\
\end{array}$ & $\begin{array}{c}23 / 14.8 \\
132 / 85.2 \\
\end{array}$ & 0.906 \\
\hline $\begin{array}{l}\text { Malignancy } \\
\text { Non- malignancy }\end{array}$ & $\begin{array}{c}4 / 50 \\
109 / 74.1\end{array}$ & $\begin{array}{c}4 / 50 \\
38 / 25.9\end{array}$ & $\begin{array}{c}8 / 5.2 \\
147 / 94.8\end{array}$ & 0.134 \\
\hline $\begin{array}{l}\text { CTD } \\
\text { Non- CT }\end{array}$ & $\begin{array}{l}2 / 66.7 \\
111 / 73\end{array}$ & $\begin{array}{l}1 / 33.3 \\
40 / 27\end{array}$ & $\begin{array}{c}3 / 1.9 \\
152 / 98.1\end{array}$ & 0.806 \\
\hline $\begin{array}{l}\text { Other diseases } \\
\text { Non-other diseases }\end{array}$ & $\begin{array}{l}18 / 62.1 \\
95 / 75.4\end{array}$ & $\begin{array}{l}11 / 37.9 \\
31 / 24.6\end{array}$ & $\begin{array}{c}29 / 18.7 \\
126 / 81.3\end{array}$ & 0.145 \\
\hline Non-comorbid & $31 / 73.8$ & $11 / 26.2$ & $42 / 27.1$ & 0.877 \\
\hline
\end{tabular}

${ }^{*} p<0.05$ statistically significant, Chi-Square test. DM: diabetes mellitus, HT: hypertension, CVSD: cardiovascular system disease, CPD: chronic pulmonary disease CTD: connective tissue disease

Table 2. Baseline demographics, CT involvement, and laboratory parameters of the study population classified by the presence of comorbidity.

\begin{tabular}{|c|c|c|c|c|}
\hline Parameters & $\begin{array}{c}\text { Comorbidity }(+) \\
(\mathrm{N}=113) \\
(\mathrm{N} / \%) \\
\end{array}$ & $\begin{array}{c}\text { Comorbidity (-) } \\
(\mathrm{N}=42) \\
(\mathrm{N} / \%) \\
\end{array}$ & $\begin{array}{c}\text { All patients } \\
(\mathrm{N}=155) \\
(\mathrm{N} / \%) \\
\end{array}$ & p-value \\
\hline $\begin{array}{c}\text { Gender }^{1} \\
\text { Female } \\
\text { Male } \\
\end{array}$ & $\begin{array}{l}47 / 74.6 \\
66 / 71.7\end{array}$ & $\begin{array}{l}16(25.4 \%) \\
26(28.2 \%)\end{array}$ & $\begin{array}{l}63(40.6 \%) \\
92(59.3 \%)\end{array}$ & 0.694 \\
\hline $\begin{array}{l}\text { Oxygen requirement }^{1} \\
\text { Mild } \\
\text { Severe }\end{array}$ & $\begin{array}{l}45 / 71.4 \\
68 / 73.9\end{array}$ & $\begin{array}{l}18(28.6 \%) \\
24(26.1 \%)\end{array}$ & $\begin{array}{l}63(40.6 \%) \\
92(59.4 \%)\end{array}$ & 0.732 \\
\hline $\begin{array}{c}\text { CT involvement }^{1} \\
\text { Below 50\% } \\
\text { Oover 50\% } \\
\end{array}$ & $\begin{array}{c}59 / 73.7 \\
54 / 72 \\
\end{array}$ & $\begin{array}{c}21(26.3 \%) \\
21(28 \%) \\
\end{array}$ & $\begin{array}{l}80(51.6 \%) \\
75(48.4 \%) \\
\end{array}$ & 0.806 \\
\hline $\begin{array}{c}\text { Mortality }^{1} \\
\text { Exitus } \\
\text { Alive }\end{array}$ & $\begin{array}{l}31 / 73.8 \\
82 / 27.1\end{array}$ & $\begin{array}{l}11(26.2 \%) \\
31(27.4 \%)\end{array}$ & $42(27.1 \%) 113(72.9 \%)$ & 0.877 \\
\hline $\operatorname{Age}^{2}$ & $69(35-95)$ & $57.5(31-94)$ & $68(31-95)$ & 0.001 \\
\hline Duration of hospitalization $^{2}$ & $10(1-55)$ & $7(3-60)$ & $9(1-60)$ & 0.369 \\
\hline Lymphocyte $^{2}(0.9-3.4 \mathrm{~K} / \mathrm{uL})$ & $900(200-3400)$ & $950(200-2600)$ & $0.90(0.20-3.40)$ & 0.957 \\
\hline Lymphocyte \% ${ }^{2}(25-46 \mathrm{~K} / \mathrm{uL})$ & $13.1(1.9-49.3)$ & $18(1-36.2)$ & $15.0(1-49.3)$ & 0.137 \\
\hline $\operatorname{CRP}^{2}(0-5 \mathrm{mg} / \mathrm{L})$ & $92.1(2.2-139.4)$ & $90.6(7.40-132)$ & $92.1(2.20-139.4)$ & 0.811 \\
\hline LDH (1-248U/L) & $336(127-1884)$ & $399.5(183-885)$ & $351(127-1884)$ & 0.147 \\
\hline $\operatorname{Troponin}^{2}(12.6-20.7 \mathrm{ng} / \mathrm{L})$ & $9.9(1.70-2327)$ & $7(1.6-1654)$ & $9.4(1.6-2327)$ & 0.115 \\
\hline Ferritin $^{2}$ (23.9-366.2 ug/L) & $233.7(11.3-1500)$ & $317(21.4-1500)$ & $245.9(11.3-1500)$ & 0.327 \\
\hline Fibrinogen $^{2}(170-420$ mg/dL) & $5.74(1.47-10.25)$ & $5.82(2.79-11)$ & $5.75(1.47-11)$ & 0.148 \\
\hline D-Dimer $^{2}(0-0.5 \mathrm{mg} / \mathrm{L})$ & $0.38(0.03-17.1)$ & $0.29(0.02-7.70)$ & $0.37(0.02-17.1)$ & 0.503 \\
\hline
\end{tabular}

CT: computed tomography. CRP: C-reactive protein. LDH: Lactate dehydrogenase. 
When the survivor and the non-survivor group were compared, the severity of CT involvement, high levels of oxygen requirement, and laboratory parameters such as lymphocyte, lymphocyte ratio, lactate dehydrogenase (LDH), C-reactive protein (CRP), troponin, and ferritin were found to be associated with mortality $(p<0.05)$ (Table 3$)$.
Oxygen requirement was high in $88 \%$ of those with CT involvement above $50 \%$ and $32.5 \%$ of those with CT involvement of less than $50 \%$ $(p<0.05)$. A decrease in the lymphocytes and lymphocyte ratios and an increase in $\mathrm{LDH}$, CRP, troponin, ferritin, D-dimer, and fibrinogen values were found to be significant in the group with severe CT involvement group compared to the other group $(p<0.05)$, Table 4$)$.

Table 3. Baseline demographics, CT involvement, and laboratory parameters of the study population classified by the overall mortality.

\begin{tabular}{|c|c|c|c|c|}
\hline Parameters & $\begin{array}{c}\text { Survivor } \\
(\mathrm{N}=113) \\
\mathrm{N} / \%\end{array}$ & $\begin{array}{c}\text { Non-survivor } \\
(\mathrm{N}=42) \\
\mathrm{N} / \%\end{array}$ & $\begin{array}{l}\text { All patients } \\
\begin{array}{c}(\mathrm{N}=155) \\
\mathrm{N} / \%\end{array}\end{array}$ & $p$-value \\
\hline $\begin{array}{c}\text { Gender }^{1} \\
\text { Female } \\
\text { Male }\end{array}$ & $\begin{array}{c}51 / 81 \\
62 / 67.4\end{array}$ & $\begin{array}{c}12 / 19 \\
30 / 32.6\end{array}$ & $\begin{array}{l}63 / 40.6 \\
92 / 59.3\end{array}$ & 0.062 \\
\hline $\begin{array}{l}\text { Oxygen requirement }^{1} \\
\text { Mild } \\
\text { Severe }\end{array}$ & $\begin{array}{l}62 / 98.4 \\
51 / 55.4\end{array}$ & $\begin{array}{c}1 / 1.6 \\
41 / 44.6\end{array}$ & $\begin{array}{l}63 / 40.6 \\
92 / 59.4\end{array}$ & $<0.001$ \\
\hline $\begin{array}{c}\text { CT involvement } \\
\text { Below }^{\mathbf{5 0} \%} \\
\text { Over } \mathbf{5 0 \%}\end{array}$ & $\begin{array}{l}75 / 93.7 \\
38 / 50.7\end{array}$ & $\begin{array}{c}5 / 6.3 \\
37 / 49.3\end{array}$ & $\begin{array}{l}80 / 51.6 \\
75 / 48.4\end{array}$ & $<0.001$ \\
\hline \multicolumn{5}{|c|}{$\operatorname{Median}(\min -\mathbf{m a x})$} \\
\hline $\mathrm{Age}^{2}$ & $61(31-95)$ & $70(48-94)$ & $68(31-95)$ & 0.002 \\
\hline Duration of hospitalization $^{2}$ & $7(3-55)$ & $22.5(1-60)$ & $9(1-60)$ & $<0.001$ \\
\hline Lymphocyte $^{2}(0.9-3.4 \mathrm{~K} / \mathrm{uL})$ & $1000(200-3400)$ & $600(200-2000)$ & $0.90(0,20-3.40)$ & $<0.001$ \\
\hline 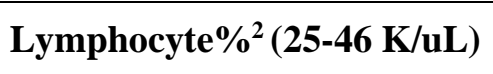 & $18.3(1,9-49.3)$ & $9.45(1-30.9)$ & $15.0(1-49.3)$ & $<0.001$ \\
\hline $\operatorname{CRP}^{2}(0-5 \mathrm{mg} / \mathrm{L})$ & $68.1(2.2-139.4)$ & $123(3.5-132.4)$ & $92.1(2.2-139.4)$ & $<0.001$ \\
\hline LDH $^{2}(1-248 U / L)$ & $337(127-1884)$ & $422(192-1375)$ & $351(127-1884)$ & 0.001 \\
\hline $\operatorname{Troponin}^{2}(12.6-20.7 \mathrm{ng} / \mathrm{L})$ & $7.7(1.6-1654.4)$ & $18.4(2.2-2327$ & $9.4(1.6-2327)$ & $<0.001$ \\
\hline Ferritin $^{2}(23.9-366.2 \mathrm{ug} / \mathrm{L})$ & $214.3(14.8-1500)$ & $493.9(11.3-1500)$ & $245.9(11.3-1500)$ & $<0.001$ \\
\hline Fibrinogen $^{2}(170-420$ g/dL $)$ & $5.67(2.67-10.25)$ & $5.95(1.47-11)$ & $5.75(1.47-11)$ & 0.148 \\
\hline D-dimer $^{2}(0-0.5$ mg/L $)$ & $0.39(0.02-7.7)$ & $0.33(0.03-17.1)$ & $0.37(0.02-17.1)$ & 0.123 \\
\hline
\end{tabular}

* $p<0.05$ statistically significant, ${ }^{1}$ Chi-Square test ${ }^{2}$ Mann-Whitney U test. CRP: C-reactive protein. LDH: Lactate dehydrogenase. 
Table 4. Oxygen requirement and laboratory parameters of the study population classified by the severity of CT involvement.

\begin{tabular}{|c|c|c|c|c|}
\hline Parameters & $\begin{array}{c}\text { CT involvement } \\
\text { mild } \\
(\mathbf{n}=\mathbf{8 0}) \\
\mathrm{N} / \%\end{array}$ & $\begin{array}{c}\text { CT involvement } \\
\text { severe } \\
(\mathrm{n}=75) \\
\mathrm{N} / \%\end{array}$ & $\begin{array}{l}\text { All patients } \\
(\mathrm{n}=155)\end{array}$ & p-value \\
\hline $\begin{array}{l}\text { Oxygen requirement }^{1} \\
\quad \text { Mild } \\
\text { Severe }\end{array}$ & $\begin{array}{l}54 / 85.7 \\
26 / 28.3\end{array}$ & $\begin{array}{c}9 / 14.3 \\
66 / 71.7\end{array}$ & $\begin{array}{l}63 / 40.6 \\
92 / 59.4\end{array}$ & $<0.001$ \\
\hline \multicolumn{5}{|c|}{ Median (min-max) } \\
\hline Duration of hospitalization $^{2}$ & $7(3-31)$ & $16(1-60)$ & $9(1-60)$ & $<0.001$ \\
\hline $\begin{array}{l}\text { Lymphocyte }^{2} \\
(0.9-3.4 \mathrm{~K} / \mathrm{uL})\end{array}$ & $1.30(0.20-3.40)$ & $0.70(0.20-2.60)$ & $0.90(0,20-3.40)$ & $<0.001$ \\
\hline $\begin{array}{l}\text { Lymphocyte\% }^{2} \\
(25-46 \mathrm{~K} / \mathrm{uL})\end{array}$ & $19.6(1.90-49.3)$ & $9.3(1-30.9)$ & $15.0(1-49.3)$ & $<0.001$ \\
\hline $\begin{array}{l}\text { CRP }^{2} \\
(0-5 \mathrm{mg} / \mathrm{L})\end{array}$ & $51.4(2.20-139.4)$ & $120.8(3.5-133.8)$ & $\begin{array}{c}92.1(2.20- \\
139.4)\end{array}$ & $<0.001$ \\
\hline $\begin{array}{l}\mathrm{LDH}^{2} \\
(1-248 \mathrm{U} / \mathrm{L})\end{array}$ & $291(172-868)$ & $440(127-1884)$ & $351(127-1884)$ & $<0.001$ \\
\hline $\begin{array}{l}\text { Troponin }^{2} \\
(12.6-20.7 \text { ng/L) }\end{array}$ & $7.2(1.6-203)$ & $12.7(1.7-2327)$ & $9.4(1.6-2327)$ & $<0.001$ \\
\hline $\begin{array}{l}\text { Ferritin }^{2} \\
(23.9-366.2 \mathrm{ug} / \mathrm{L})\end{array}$ & 196.2(21.4-1500) & $455.7(11.3-1500)$ & $\begin{array}{c}245.9(11.3- \\
1500) \\
\end{array}$ & $<0.001$ \\
\hline $\begin{array}{l}\text { Fibrinogen }^{2} \\
(170-420 \mathrm{mg} / \mathrm{dL})\end{array}$ & $5.22(1.47-9.9)$ & $6.4(2.02-11)$ & $5.75(1.47-11)$ & $<0.001$ \\
\hline $\begin{array}{l}\text { D-Dimer } \\
(0-0.5 \text { mg/L) }\end{array}$ & $0.31(0.04-4.95)$ & $0.46(0.02-17.1)$ & $0.37(0.02-17.1)$ & 0.014 \\
\hline
\end{tabular}

\section{Discussion}

In a meta-analysis including ten studies in China, the mortality rate in COVID-19 was 5\% [7], while in a Chinese Center for Disease Control and Prevention report containing 72314 cases of COVID-19, the mortality was reported as $2.3 \%, 14.8 \%$ in patients over 80 years old, and $49 \%$ in critical cases [8]. In another study, the mortality rate in inpatient COVID-19 patients reached $28.3 \%$ [2]. The overall mortality was $27 \%$ in our study.

While the most common comorbidities in COVID-19 patients were HT (30\%), DM
(19\%), and coronary heart disease $(8 \%)$ [2], in patients with ARDS, they were HT (27\%), DM (19\%), and cardiovascular diseases (6\%) [9]. Uçan et al. reported in their study that $62.1 \%$ of the patients had comorbidity, and hypertension was the most common [10]. In our study, comorbidity was observed in $73 \%$ of our patients, and in order of frequency, HT was 49.7\%, DM 29\%, DM+HT 21.3\%, CPD $14.8 \%$, CVSD 9\%, malignancy $5.2 \%$, CDD $1.9 \%$, other diseases (a few diseases that we did not group, such as goiter, chronic kidney failure) $18.7 \%$, and the non-comorbid patient rate was $27.1 \%$. 
However, when we grouped the diseases as presence/absence of comorbid diseases and grouped them individually, no relation was found with mortality $(p>0.05)$.

Angiotensin-converting enzyme inhibitors and angiotensin receptor blockers (ARB) increase ACE2, and virus binding also increases [11,12]. The increased soluble ACE2 in the circulation can bind SARS-CoV-2, reducing its ability to damage the lungs and other ACE2-bearing organs [13]. Therefore, $\mathrm{ACE}$ inhibitors and ARBs may reduce the potential for patients with COVID19 to develop acute respiratory distress syndrome, myocarditis, or acute kidney injury. ARBs have been proposed as a treatment for COVID-19 and its complications [14]. There is no evidence yet that hypertension is associated with the consequences of COVID-19 or that the use of ACE inhibitors or ARBs during the COVID-19 pandemic is harmful or, therefore, beneficial [15]. In our study, no increase was found in mortality in patients with HT. No prolongation of hospitalization was observed (8 days (1-55) in the group with HT vs. 9.5 days (3-60) in the non-HT group, p:0.310).

In the study of Mithal et al., $47.1 \%$ of the hospitalized COVID-19 patients had Diabetes, and it was found to be associated with severe illness and mortality. HT was reported as the most common comorbidity in patients with DM [16]. In another study, DM was reported as the most common comorbidity in COVID-19 and was associated with mortality [3]. Mortality rates of $7.3 \%$ [8] have been reported in diabetic patients in China and over 30\% in Europe [17]. Although the mechanism underlying the relationship between diabetes and COVID-19 severity remains unclear, Yang et al.[18] indicated that ACE2 could be strongly expressed in pancreatic islet cells, suggesting that these cells may be targeted by SARS-CoV-
2 [19]. Metabolic disorders may impair macrophage and lymphocyte function, resulting in poor immune function [20] and may make individuals more susceptible to disease complications [21]. Diabetes COVID-19 has also been associated with increased severity of complications and symptoms [22]. This may be partly due to increased risk of endothelial dysfunction, increased systemic inflammatory response, micro-and macrovascular disease, and diabetic cardiomyopathy [23,24,35,26]. Despite the presence of DM in $31-80 \%$ of those who died due to COVID-19 in studies [16,17], DM was associated with ICU hospitalization and duration of hospitalization in the multivariate analysis, but no correlation with mortality was demonstrated [28].

In the study of Guo et al, higher CRP, ferritin, interleukin-6 (IL-6), sedimentation levels were found, and Zhu et al. found an increase in the incidence of lymphopenia, higher CRP, and procalcitonin levels in diabetic patients [29,30]. In our study, we did not determine increased mortality in patients with diabetes. At the same time, oxygen requirement was not high, and CT involvement was not more severe in this group. Also, we did not detect increased inflammation parameters. For these possible reasons, the duration of hospitalization was also found to be shorter (8 days (1-31) in the diabetes group vs. 10 days (3-60) in the non-diabetes group, $\mathrm{p}$ : 0.052).

In their study, which included 1590 hospitalized COVID-19 patients, Guan et al. reported that the most common comorbidities among infected individuals were hypertension $(16.9 \%)$ and diabetes $(8.2 \%)$, and patients with two or more comorbidities (8.2\%) [31]. In another study, 149 of 1138 patients (13.09\%) had two comorbidities, and hypertension+DM was the most commonly observed comorbid disease. The co-existence of more than one 
comorbidity significantly increased the risk of death. In multivariate analysis, more than four times mortality risk was observed in patients with more than three comorbidities. Ageclassified analysis revealed that the effect of comorbidities on death decreased with increasing age [32]. In our study, the association of DM + HT was $21.3 \%$, and its relationship with mortality was not significant, but the length of hospital stay was found to be significantly shorter (DM+HT co-existence 7 days (1-31) vs. non-DM+HT 10 days (3-60), p: 0.031). While the expected issue was the prolonged duration of hospitalization, the fact that the oxygen requirement was not high, the CT involvements were not severe, and the inflammation markers were not high in these comorbid groups may explain this result.

Although the prevalence of COPD is low in COVID-19, these patients' mortality and severe disease rates have been reported to be high [4]. Viral infections cause an increase in systemic inflammation in COPD patients [33,34]. Comorbid conditions, which are usually associated with COPD patients, may also be associated with increased hospitalization $[35,36]$.

Questions remain about the effects of inhaled (ICS) and systemic corticosteroids, short- and long-acting $\beta 2$-agonists, and short- and longacting muscarinic antagonists in alleviating or exacerbating COVID-19. ACE-2 expression in airway epithelial cells from patients with asthma is reduced in those receiving ICS compared to those not using ICS, raising the possibility that ICS exposure may reduce viral entry. It is not clear that the same relationship is valid in the COPD airway, which increases susceptibility to pneumonia following ICS use [37]. In our study, no significant relationship was found between the presence of COPD and mortality.
Asthma comorbidity was found to be more common in non-severe cases of COVID-19. Compared with patients with asthma, COPD patients were found to have increased mortality and a higher risk of developing severe disease and ARDS. In this study, downregulation of ACE2 protein expression in the lower airways was found in asthmatics compared to controls and patients with COPD. Besides, asthmatics with higher peripheral blood eosinophilia show lower ACE2 expression, indicating potential regulation of ACE2 expression by type 2 inflammation in asthmatics [38]. Our study created a chronic pulmonary disease category, including interstitial lung disease without distinction between asthma and COPD. In this group, no increase in mortality and $n$ prolonged hospitalization (8 days (4-31) in the group with CPD vs. 10 days (1-60) in the group without CPD) were observed ( $p>0.005)$.

When patients with CVSD have COVID-19, the rate of complications such as myocardial infarction, malignant arrhythmia, mesenteric infarction, cardiovascular death, heart failure, myocardial suppression increases [39]. COVID-19 is associated with endothelitis and myocarditis $[40,41]$. It is believed that SARS CoV-2 can elicit an intense systemic inflammatory response, and the atherosclerotic plaque may become unstable and more prone to rupture, leading to higher myocardial infarction rates and faster systolic dysfunction and heart failure [42]. However, in our ASCVD group, which consisted of 14 patients, no increase in mortality and no prolonged hospitalization ( 8 days (4-19) in patients with ASCVD vs. 9 days (1-60) in patients without ASCVD) were determined $(\mathrm{p}>0.05)$.

In the study of Jarahzadeh et al., cancer was not among the most common comorbidities in confirmed COVID-19 patients [5]. A lower rate of mechanical ventilation or death has been 
reported in patients with cancer infected with COVID-19 than in patients without cancer [5]. In a nationwide study including 1590 hospitalized COVID-19 patients, Guan et al. reported that 18 cases $(1.1 \%)$ had a history of malignancy [31]. In another study, those with a history of malignancy were found to be $6 \%$ [43]. A meta-analysis showed that $2 \%$ of COVID-19 patients had a history of malignancy, with a higher risk of severe symptoms in the cancer group with a history of chemotherapy or surgery within one month (75\% vs. $43 \%$ ) [44].

In COVID-19 patients with lung cancer, higher disease severity and higher rates of intensive care admission and mechanical ventilation requirement have been reported compared to other malignancies and the general population [45]. Multicenter studies have reported a high mortality rate of $33 \%$ in thoracic malignancies [46]. In our study, patients with cancer were few, and there was no significant difference in terms of mortality and hospitalization (22.5 (345) days in the cancer group, 9 (1-60) days in the non-cancer group) ( $p>0.05)$. Although the number of our patients was low in terms of connective tissue diseases, we did not find any effect on mortality and duration of stay (9 days (1-60) in non-CDD patients vs. 24 days (14-27) in patients with CDD) $(\mathrm{p}>0.05)$.

In the study conducted by Uçan et al., the mean age was reported as $61.9 \pm 20.1$ years [10]. In our study, the mean age of the patients was 68 years (31-95), and the relationship between mortality and age was statistically significant (61 years (31-95) in survivors vs. 70 years (48-94) in nonsurvivors, p: 0.002). The group with comorbid diseases was older. (69 years (35-95) vs. 57.5 years (31-94), p: 0.001). An analysis of 77,932 patients (41510 men) infected with COVID-19 indicated that men had 1.71 times higher mortality rate than women [47]. The fact that genetic factors or risk-increasing factors such as diabetes, hypertension, and coronary artery disease are more common in men may explain this increase [1]. The increased smoking rate in men may also be associated with increased mortality [48]. Also, the stronger immune system of women and the location of most of the genes that regulate immunity on the $\mathrm{X}$ chromosome may have turned this ratio in favor of women [49]. Biological gender is also related to $\mathrm{T}$ cells and autoimmune response; for example, women secrete higher amounts of interferon than men [50] while testosterone suppresses immunity, estrogens activate it [51]. Similar to the male dominance in the literature ${ }^{8}$, $59.3 \%$ of all patients in our study consisted of men. Comorbid diseases were not more common in males, and no gender difference was found in mortality rates $(p>0.05)$.

In the study of Uçan et al., Ferritin, CRP, troponin, d-dimer, $\mathrm{LDH}, \quad$ and neutrophil/lymphocyte ratio were found to be high in the mortal group [10]. In our study, lymphocyte, lymphocyte ratio, LDH, CRP, troponin, ferritin were also associated with mortality ( $p>0.005)$, but no significant correlation was found with fibrinogen and $\mathrm{d}$ dimer ( $\mathrm{p}>0.05)$.

Xie et al. stated that dyspnea and hypoxia despite oxygen support at admission were strong independent predictors of mortality. $99 \%$ of patients with an oxygen saturation level of $90 \%$ or more survived, while $69 \%$ of those with oxygen saturation of $90 \%$ or less despite oxygen support died [52]. In our study, it was the increase in oxygen requirement that affected mortality ( $p>0.005$ ). Chatterjee et al. also found higher mortality in hospitalized COVID-19 patients with oxygen saturation of $<92 \%$ or respiratory rate of $>22 / \mathrm{min}$ [53].

Higher CRP values were found in severe pneumonia with diffuse involvement. In these 
patients, the duration of stay in the intensive care unit, ventilator support, and mortality rates was also found to be higher [54]. In our study, CT involvement of over $50 \%$ was found to be associated with mortality $(\mathrm{p}>0.005)$. Oxygen requirement was high in $88 \%$ of those with CT involvement above $50 \%$ and $32.5 \%$ of those with CT involvement of less than $50 \%$ $(\mathrm{p}<0.05)$. A decrease in lymphocytes and lymphocyte ratios and an increase in $\mathrm{LDH}$, CRP, troponin, ferritin, D-dimer, and fibrinogen values were significant in the group with severe CT involvement compared to the other group $(\mathrm{p}<0.05)$.

\section{Conclusions}

Most of our patients were patients followed up with critical pneumonia (92 out of 155 patients (59.4\%) had severe oxygen requirement, 75 (48.4\%) had more than 50\% CT involvement). We found that the presence of comorbidity did not affect mortality, while CT involvement and oxygen requirement were associated with mortality. Among the laboratory parameters, we found that lymphocyte, lymphocyte ratio, LDH, CRP, troponin, and ferritin were associated with mortality. Patients with severe CT involvement had higher oxygen requirements and higher inflammation markers. Limitations of our study are that results should be replicated with larger and more representative samples. In particular, the number of our malignancy and CDD group was low, and more extensive studies are required. Another limitation is the study population consisting of inpatients only. In terms of hospitalization, advanced age and the presence of comorbidity should be taken as criteria without hypoxemia, the severity of CT involvement, and abnormal laboratory parameters.
Funding: The author(s) received no financial support for the research, authorship, and/or publication of this article.

Conflict of Interest: The authors declare that they have no conflict of interest.

\section{Ethical statement:}

The study was approved by Local Clinical Research Ethics Committee (Date and Decision Number: 10.06.2021-189), and written informed consent was obtained from each subject.

\section{Open Access Statement}

This is an open access journal which means that all content is freely available without charge to the user or his/her institution under the terms of the Creative Commons Attribution NonCommercial License (http://creativecommons.org/licenses/bync/4.0). Users are allowed to read, download, copy, distribute, print, search, or link to the full texts of the articles, without asking prior permission from the publisher or the author.

Copyright (c) 2021: Author (s).

\section{References}

[1]Anca PS, Toth PP, Kempler P, et al. Gender differences in the battle against COVID-19: Impact of genetics, comorbidities, inflammation and lifestyle on differences in outcomes. Int $\mathrm{J}$ Clin Pract. 2021;75(2):e13666.

[2]Zhou F, Yu T, Du R, et al. Clinical course and risk factors for mortality of adult inpatients with COVID-19 in Wuhan, China: a retrospective cohort study. Lancet. 2020;395(10229):1054-62.

[3]Apicella M, Campopiano MC, Mantuano M, et al. COVID-19 in people with diabetes: understanding the reasons for worse outcomes. Lancet Diabetes Endocrinol. 2020;8(9):782-92. 
[4]Alqahtani JS, Oyelade T, Aldhahir AM, et al. Prevalence, Severity and Mortality associated with COPD and Smoking in patients with COVID-19: A Rapid Systematic Review and Meta-Analysis. PLoS One. 2020;15(5):e0233147.

[5]Jarahzadeh MH, Asadian F, Farbod M, et al. Cancer and Coronavirus Disease (COVID19): Comorbidity, Mechanical Ventilation, and Death Risk. J Gastrointest Cancer. 2021;52(1):80-84.

[6][6] World Health Organization, et al. Clinical management of severe acute respiratory infection ( SARI) when COVID19 disease is suspected: interim guidance, 13 March 2020. World Health Organization, 2020.

[7]Li L, Huang T, Wang Y, et al. COVID-19 patients' clinical characteristics, discharge rate, and fatality rate of meta-analysis. J Med Virol. 2020;92 (6):1-7.

[8]Wu Z, McGoogan JM. Characteristics of and Important Lessons From the Coronavirus Disease 2019 (COVID-19) Outbreak in China: Summary of a Report of 72314 Cases From the Chinese Center for Disease Control and Prevention. JAMA. 2020 ;323(13):1239-42.

[9]Wu C, Chen X, Cai Y, et al. Risk Factors Associated With Acute Respiratory Distress Syndrome and Death in Patients With Coronavirus Disease 2019 Pneumonia in Wuhan, China. JAMA Intern Med. 2020;180(7):934-43.

[10]Ucan ES, Ozgen Alpaydin A, et al. DEU COVID Study Group. Pneumonia severity indices predict prognosis in coronavirus disease-2019. Respir Med Res. 2021;79:100826.

[11]Ferrario CM, Jessup J, Chappell MC, et al. Effect of angiotensin-converting enzyme inhibition and angiotensin II receptor blockers on cardiac angiotensin-converting enzyme 2. Circulation. 2005;111(20):260510.

[12] Furuhashi M, Moniwa N, Mita T, et al. Urinary angiotensin-converting enzyme 2 in hypertensive patients may be increased by olmesartan, an angiotensin II receptor blocker. Am J Hypertens. 2015;28(1):1521.

[13]Batlle D, Wysocki J, Satchell K. Soluble angiotensin-converting enzyme 2: a potential approach for coronavirus infection therapy? Clin Sci (Lond). 2020;134(5):54345.

[14] Gurwitz D. Angiotensin receptor blockers as tentative SARS-CoV-2 therapeutics. Drug Dev Res. 2020;81(5):537-40.

[15]Schiffrin EL, Flack JM, Ito $S$, et al. Hypertension and COVID-19. Am J Hypertens. 2020;33(5):373-74.

[16] Mithal A, Jevalikar G, Sharma R, et al. High prevalence of diabetes and other comorbidities in hospitalized patients with COVID-19 in Delhi, India, and their association with outcomes. Diabetes Metab Syndr. 2021;15(1):169-75.

[17] Caballero AE, Ceriello A, Misra A, et al. COVID-19 in people living with diabetes: An international consensus. J Diabetes Complications. 2020;34(9):107671.

[18] Yang JK, Lin SS, Ji XJ, et al. Binding of SARS coronavirus to its receptor damages islets and causes acute diabetes. Acta Diabetol. 2010;47(3):193-99.

[19]Bernardi S, Tikellis C, Candido R, et al. ACE2 deficiency shifts energy metabolism towards glucose utilization. Metabolism. 2015;64(3):406-15.

[20]Dooley KE, Chaisson RE. Tuberculosis and diabetes mellitus: convergence of two epidemics. Lancet Infect Dis. 2009;9(12):737-46. 
[21][Badawi A, Ryoo SG. Prevalence of comorbidities in the Middle East respiratory syndrome coronavirus (MERS-CoV): a systematic review and meta-analysis. Int $\mathbf{J}$ Infect Dis. 2016;49:129-33.

[22] Stoian AP, Banerjee Y, Rizvi AA, et al. Diabetes and the COVID-19 Pandemic: How Insights from Recent Experience Might Guide Future Management. Metab Syndr Relat Disord. 2020;18(4):173-75.

[23]Jia G, Hill MA, Sowers JR. Diabetic Cardiomyopathy: An Update of Mechanisms Contributing to This Clinical Entity. Circ Res. 2018;122(4):624-38.

[24] Calles-Escandon J, Cipolla M. Diabetes and endothelial dysfunction: a clinical perspective. Endocr Rev. 2001;22(1):36-52.

[25] Donath MY, Shoelson SE. Type 2 diabetes as an inflammatory disease. Nat Rev Immunol. 2011;11(2):98-107.

[26] Ceriello A, Stoian AP, Rizzo M. COVID-19 and diabetes management: What should be considered? Diabetes Res Clin Pract. 2020; 163: 108151.

\section{[27] Report-COVID-}

2019_7_may_2020.Pdf.Accessed.

https://www.epicentro.iss.it/en/coronavirus/ bollettino/Report-COVID-

2019_7_may_2020.pdf, Accessed 6th Nov 2020

[28] Al-Salameh A, Lanoix JP, Bennis Y, et al. Characteristics and outcomes of COVID-19 in hospitalized patients with and without diabetes. Diabetes Metab Res Rev. 2021 ;37(3):e3388.

[29]Guo W, Li M, Dong Y. Diabetes is a risk factor for the progression and prognosis of COVID-19. Diabetes Metab Res Rev. 2020: e3319.

[30]Zhu L, She ZG, Cheng X, et al. Association of Blood Glucose Control and Outcomes in Patients with COVID-19 and Pre-existing
Type 2 Diabetes. Cell Metab. 2020;31(6):1068-1077.e3.

[31] Guan WJ, Liang WH, Zhao Y, et al. China Medical Treatment Expert Group for COVID-19. Comorbidity and its impact on 1590 patients with COVID-19 in China: a nationwide analysis. Eur Respir J. 2020;55(5):2000547.

[32]Lu QB, Jiang WL, Zhang X, et al. Comorbidities for fatal outcome among the COVID-19 patients: A hospital-based casecontrol study. J Infect. 2021;82(1):159-98.

[33] Aaron SD, Donaldson GC, Whitmore GA, et al. Time course and pattern of COPD exacerbation onset. Thorax. 2012;67(3):238-43.

[34] Williams NP, Ostridge K, Devaster JM, et al. AERIS Study Group. Impact of radiologically stratified exacerbations: insights into pneumonia aetiology in COPD. Respir Res. 2018;19(1):143.

[35] Terzano C, Colamesta V, Unim B, et al. Chronic obstructive pulmonary disease (COPD) exacerbation: impact of comorbidities on length and costs during hospitalization. Eur Rev Med Pharmacol Sci. 2017;21(16):3680-89.

[36]Hurst JR, Skolnik N, Hansen GJ, et al. Understanding the impact of chronic obstructive pulmonary disease exacerbations on patient health and quality of life. Eur J Intern Med. 2020;73:1-6.

[37]Halpin DMG, Singh D, Hadfield RM. Inhaled corticosteroids and COVID-19: a systematic review and clinical perspective. Eur Respir J. 2020;55(5):2001009.

[38] Song J, Zeng M, Wang H, et al. Distinct effects of asthma and COPD comorbidity on disease expression and outcome in patients with COVID-19. Allergy. 2021;76(2):48396. 
[39] Khera A, Baum SJ, Gluckman TJ, et al. Continuity of care and outpatient management for patients with and at high risk for cardiovascular disease during the COVID-19 pandemic: A scientific statement from the American Society for Preventive Cardiology. Am J Prev Cardiol. 2020;1:100009.

[40]Beşler MS, Arslan H. Acute myocarditis associated with COVID-19 infection. Am J Emerg Med. 2020;38(11):2489.e1-2489.e2.

[41] Teuwen LA, Geldhof V, Pasut A, et al. COVID-19: the vasculature unleashed. Nat Rev Immunol. 2020;20(7):389-91.

[42] Shi S, Qin M, Shen B, et al. Association of Cardiac Injury With Mortality in Hospitalized Patients With COVID-19 in Wuhan, China. JAMA Cardiol. 2020;5(7):802-810.

[43] Richardson S, Hirsch JS, Narasimhan M, et al. Presenting Characteristics, Comorbidities, and Outcomes Among 5700 Patients Hospitalized With COVID-19 in the New York City Area. JAMA. 2020;323(20):2052-59.

[44]Desai A, Sachdeva S, Parekh T, et al. COVID-19 and Cancer: Lessons From a Pooled Meta-Analysis. JCO Glob Oncol. 2020;6:557-59.

[45] Peravali M, Joshi I, Ahn J, et al. Systematic Review and Meta-Analysis of Clinical Characteristics and Outcomes in Patients With Lung Cancer with Coronavirus Disease 2019. JTO Clin Res Rep. 2021;2(3):100141.

[46] Garassino MC, Whisenant JG, Huang LC, et al. TERAVOLT investigators. COVID-19 in patients with thoracic malignancies (TERAVOLT): first results of an international, registry-based, cohort study. Lancet Oncol. 2020;21(7):914-22.
[47]Wei X, Xiao YT, Wang J, et al. Sex differences in severity and mortality among patients with COVID-19: evidence from pooled literature analysis and insights from integrated bioinformatic analysis. arXiv: PopulEvol.2020.

https://arxiv.org/abs/2003.13547

[48] Mackay J, Eriksen M. The Tobacco Atlas. Geneva: World Health Organization; 2002.p. 24-25.

[49] Walter LA, McGregor AJ. Sex- and Genderspecific Observations and Implications for COVID-19. West J Emerg Med. 2020;21(3):507-509.

[50]Ngo ST, Steyn FJ, McCombe PA. Gender differences in autoimmune disease. Front Neuroendocrinol. 2014;35(3):347-69.

[51]Beagley KW, Gockel CM. Regulation of innate and adaptive immunity by the female sex hormones oestradiol and progesterone. FEMS Immunol Med Microbiol. 2003;38(1):13-22.

[52] Xie J, Covassin N, Fan Z, et al. Association Between Hypoxemia and Mortality in Patients With COVID-19. Mayo Clin Proc. 2020;95(6):1138-47.

[53] Chatterjee NA, Jensen PN, Harris AW, et al. Admission respiratory status predicts mortality in COVID-19. Influenza Other Respir Viruses. 2021:10.1111/irv.12869.

[54] Carvalho ARS, Guimarães A, Garcia TSO, et al. Estimating COVID-19 Pneumonia Extent and Severity From Chest Computed Tomography. Front Physiol. 2021;12:617657. 